\title{
GENERAL SECONDARY EDUCATION QUALITY ASSURANCE OF UKRAINE TOWARDS EUROPEAN STANDARDS
}

ASIGURAREA CALITĂȚII ÎN ÎNVĂTTĂMÂNTUL SECUNDAR GENERAL DIN UCRAINA, CĂTRE ATINGEREA STANDARDELOR EUROPENE

\section{Oleh TOPUZOV}

\author{
Journal of Pedagogy, 2018 (1), 77 - 91 \\ https://doi.org/10.26755/RevPed/2018.1/77
}

The online version of this article can be found at: http://revped.ise.ro/category/2018-en/

\section{(c) (i) ()(2)}

This work is licensed under the Creative Commons Attribution-NonCommercial-ShareAlike 4.0 International License. 94042, USA.

Published by:

\section{INSTITUTUL DE ȘTIINȚE ALE EDUCAȚIEI}

http://www.ise.ro/

Further information about Revista de Pedagogie - Journal of Pedagogy can be found at: Editorial Policy: http://revped.ise.ro/editorial-policy/ Author Guidelines: http://revped.ise.ro/the-writer-guide-2/ 


\title{
GENERAL SECONDARY EDUCATION QUALITY ASSURANCE OF UKRAINE TOWARDS EUROPEAN STANDARDS
}

\author{
Oleh Topuzov* \\ Institute of Pedagogy of the National Academy of \\ Educational Sciences of Ukraine \\ Kyiv, Ukraine \\ proftop@ukr.net
}

\begin{abstract}
Integration of the Ukrainian education into the European Education Area under the conditions of the European choice of Ukraine is highlighted; in the context of the Ukrainian education integration into the European Education Area strategic reform tasks are outlined, i.e. to actualize the existing scientific and pedagogical potential, to implement the opportunities of the Ukrainian scholars and teachers for forecasting, programming, scientific and methodological support of cooperation with the EU priority areas in the education sector; to make strategic management decisions that will create a roadmap for the entry of the education system of Ukraine into the European Education Area; to reform the education system financing; to promote the implementation of the most up-to-date scientific approaches and educational technologies; to continue the democratization of the educational institutions' life; to improve the quality of training for future school teachers and teachers of pedagogical universities; to promote and to develop international cooperation of national educational institutions, and to ensure conditions for educational mobility. It is determined that one of the priorities of integration of the education system and the general secondary education of Ukraine, in particular, to the European Educational Area, is to ensure its quality according to European standards. According to the Law on Education from September 5, 2017, general secondary education has
\end{abstract}

* Professor, Doctor of Science in Education, Honored Worker of Science and Tehnology of Ukraine, Director of the Institute of Pedagogy of the National Academy of Educational Sciences of Ukraine. 
three levels of education: primary education lasts four years (starts at 6 years); basic secondary education lasts five years; profile secondary education lasts three years. It is concluded that the achievement of the European quality of education in Ukraine will be a powerful factor in solving the economic, political and cultural problems of European integration of our country, the development of a prosperous and democratic society. Therefore, the problem of quality assurance of education needs to be given more attention in the process of development of the national education system.

Keywords: European choice of Ukraine, European Educational Area, European standards, general secondary education, quality assurance.

\section{Rezumat}

Articolul analizează integrarea învă ământului ucrainean în spa iul educa ional european, în condi iile alegerii direc iei europene, pentru Ucraina; în contextul integrării învă ământului ucrainean în spa iul educa ional european, se eviden iază o serie de reforme strategice, cum ar fi: actualizarea poten ialului ştiin ific şi pedagogic existent, punerea în aplicare a oportunită ilor elevilor şi profesorilor ucraineni pentru prognoza, programarea, sprijinul ştiin ific şi metodic pentru cooperarea în domeniile prioritare ale educa iei; adoptarea deciziilor strategice de management, care vor crea o foaie de parcurs pentru intrarea sistemului de educa ie ucrainean în spa iul educa ional european; reformarea finan ării sistemului de învă ământ; promovarea introducerii celor mai recente abordări ştiin ifice şi a tehnologiilor educa ionale; continuarea democratizării activită ii institu iilor de învă ământ; îmbunătă irea calită ii formării viitorilor profesori şi a profesorilor universită ilor pedagogice; promovarea şi dezvoltarea cooperării interna ionale pentru institu iile na ionale de învă ământ; asigurarea condi iilor pentru mobilitatea educa ională. $S$-a stabilit ca una dintre priorită ile integrării sistemului de învă ământ, în special a învă ământului secundar general din Ucraina, în Spa iul Educa ional European, să fie asigurarea calită ii în conformitate cu standardele europene. Conform Legii educa iei din 5 septembrie 2017, învă ământul secundar general are trei niveluri de educa ie: învă ământul primar care durează patru ani (începând cu vârsta de 6 ani); învă ământul secundar de bază care durează cinci ani; învă ământ secundar de profil de trei ani. S-a ajuns la concluzia că, în Ucraina, realizarea calită ii europene a educa iei va fi un factor puternic în rezolvarea problemelor economice, politice şi culturale ale integrării europene a ării noastre, în dezvoltarea societă ii prospere şi democratice. Prin urmare, în procesul de dezvoltare a sistemului na ional de învă ământ, trebuie să se acorde mai multă aten ie problemei asigurării calită ii educa iei. 
Cuvinte-cheie: asigurarea calită ii, învă ământul secundar general, op iunea de europenizare a Ucrainei, Spa iul Educa ional European, standarde europene.

\section{Introduction}

The European choice of Ukraine has become a historical fact, and at present, European integration of our country is becoming its everyday life. It should be emphasized that this choice was made not only in the politics, but also in the minds of many of our citizens, which is a key to the irreversibility of the European vector of development of Ukraine, the best guarantee of successful progress in the chosen direction.

Ukraine's European choice is multidimensional. The agreement with the European Union (hereinafter - the EU) clarified the political and economic terms of cooperation, but Europe is not limited to political institutions and economic space. Europe is a cradle of modern civilization, a large and rich cultural and educational space with diverse traditions, which has its long and interesting history. Therefore, European integration of Ukraine involves not only political and economic cooperation, but also active educational and pedagogical cooperation, the formation of our state as a full-fledged participant in the European Education Area.

One can foresee that European integration of Ukraine will take place, first, by integrating the national education system into the European Education Area. By such integration, we mean: aligning the quality assurance standards with those used in European Union; specifically, by structuring the educational system and creating National Qualifications Framework in accordance to the European one, which was partially done in the new Law of Education of Ukraine from 2017, but still needs more detailed elaboration; competencies based education; accepting and developing European values. It is easy to specify such a significance of educational integration as without proper education, general secondary and vocational training of our citizens, it is impossible to apply or create technologies that will ensure the competitiveness of Ukrainian goods in the European market, and it is also difficult to have a thorough political and cultural dialogue, to develop a democratic European society. In order for us to integrate into Europe successfully, we need to 
ensure that the Ukrainian economy, politics, local government, education, medicine, social protection and other public institutions meet European standards. Achieving this in a short-term period of time is possible only by changing the consciousness and activities of specialists and employees who provide these types of social activities, and by attracting new technologies. Under modern conditions, it is only possible in the system of education. Therefore, the education system of Ukraine should influence the culture and behaviour, the future professional activity of our fellow citizens in such a way that they are in line with their European integration aspirations.

In order to achieve it, it is necessary to ensure a proper level of national education quality (first of all, it is the general secondary education, which is the basis of vocational education). Therefore, a set of problems arises; among them, one of the main issues is the development of teaching and methodological support for the general secondary education, which would meet the requirements for the quality of education generated by the European integration of our country.

\section{The purpose of the article}

The purpose of the article is to outline the strategic objectives of reforming general secondary education in Ukraine in the context of European choice and integration into the European Education Area, in particular in terms of quality assurance.

\section{Discussion}

2.1. Strategic tasks facing the reform of the national secondary education

Performing important European integration mission by the national education system will require a new stage in its reform. For this purpose, it is significant to achieve at least eight major strategic objectives.

Firstly, it is necessary to actualize the existing scientific and pedagogical potential, to realize the opportunities of Ukrainian scholars, teachers, research institutes, the National Academy of Educational Sciences in general for 
forecasting, programming, scientific and methodological support of priority directions of cooperation with the EU in the education area, European integration of the education system of Ukraine. Ukrainian pedagogy has the potential for this.

Secondly, based on scientific forecasts, for approving projects and programs that will be developed by scientists, it is necessary to make strategic management decisions that will create a road map for the entry of the Ukrainian education system into the European Education Area, and identify the strategic directions of the reform related to it. We need a comprehensive program for the development and reform of the education system of Ukraine for the next 10 years, through which the red thread would be the desire to integrate the national education system into the European Education Area, to achieve the European level of education quality, but at the same time to preserve its cultural peculiarity, to save and multiply the centuries-old achievements.

Thirdly, it is time to reform the financing of the education system of Ukraine. The current system of financing educational institutions is not sufficiently transparent, does not ensure the development of the tangible and technical base of educational institutions, the material interest of teachers in the results of their activities. It would be very difficult to get into Europe with such a burden. The national system's reform of financing educational institutions should be carried out in three strategic directions: firstly, diversification of funding sources (ensuring conditions for the wider involvement of sponsors and patrons, non-state target funds, which will allocate grants to educational institutions for specific educational projects, etc.); secondly, improving the financing tools of educational institutions by communities, for example, by introducing a property tax, the proceeds of which will be oriented at the needs of educational institutions for the community; thirdly, establishing a closer connection between the number and educational outcomes of students and the financial revenues of educational institutions, targeted funding for student learning, etc.

Fourthly, it is necessary to promote the implementation of the most up-todate scientific approaches and educational technologies. In this regard, the further implementation of a competence-based educational approach is very relevant. On the one hand, it will facilitate European and international 
educational cooperation (since the methodology of a competent approach is known, recognized and demanded in Europe and in the world). On the other hand, it will not prevent the implementation of national scientific theoretical and methodological developments from personality-oriented and operational approaches, because the essence of the competent approach with them is coherent. As for the implementation of modern educational technologies, we should realize that it is possible and necessary to adapt and implement based on the European experience. However, we should not limit ourselves to the introduction of well-known didactic and methodological layouts. Europe will be interested not in the passive replication of its educational experience, but in the productive and original one that we can create and show. Therefore, it is necessary to focus on the creation of their educational technologies, to preserve and develop the existing base of applied scientific and pedagogical research at the outset.

Fifthly, it is necessary to continue the democratization of the educational institutions' life. First of all, this task is fulfilled by delegating greater powers and responsibility to the educational institutions and the further development of self-government institutions, wider involvement of local communities in making strategic decisions and solving problems of institutions, ensuring conditions for effective social partnership, etc.

Sixthly, the achievement of the European quality of preschool and general secondary education is impossible without improving the quality of the training of the future school teachers and teachers of pedagogical universities, without the further development of postgraduate pedagogical education. Consequently, attention should be paid to higher pedagogical educational institutions and postgraduate pedagogical education institutions: to identify and implement new tasks and content of education as a result of European integration, to introduce innovative methods, organizational forms and means of teaching, to conduct appropriate mass scientific events, to create conditions for the training of the best teachers, lecturers and students in European countries.

Seventhly, it is necessary to promote and develop international cooperation of homeland educational institutions. Applying modern information and communication technologies makes it possible to implement it with minimal material costs. 
Finally, it is necessary to ensure conditions for educational mobility. It applies not only to graduates of second educational institutions and students, but also to schoolchildren. There is no need to be fearful of the competition from other European educational institutions. It should be sought as it is a powerful incentive to improve the quality of national education, optimize the educational activities of Ukrainian educational institutions, attract foreign educational experience, and introduce educational innovations. Students who strive to take advantage of educational mobility will place additional requirements on their own and in educational institutions. It will increase the quality of education (in particular, foreign languages). It is worth mentioning that many of the national teachers and psychologists of the nineteenth and twentieth centuries had benefited from European education.

These strategic tasks do not cover all the problems of Ukraine's educational system integration into the European Education Area, but they point to the most important problems without which we will not achieve the expected results.

The unconditional advantage of the EU integration potential lies in the attentive and respectful attitude towards the cultural features of European countries that have already become or just seek to become its members. It is also regarded to education systems. Member States are responsible for education in the European Union, and EU bodies play only an auxiliary role. EU institutions contribute to the development of quality education by: encouraging cooperation between Member States, promoting continuous education of EU citizens, carrying out activities aimed at enhancing the EU citizens' mobility, developing joint educational programs, exchanging information and studying EU languages. The European community does not require its members to level out the peculiarities of their educational systems, which are determined by cultural and historical factors, which define the national character. However, joining the EU integration into the European Education Area will provide the achievement of a new, higher quality of the national education, in particular, the general secondary one. In fact, that lies in the achievement of European standards for the quality of general secondary education (although they are still unwritten). Without proper education, we will not achieve European standards for quality of life. Indeed, in modern Europe, the quality and level of education determine the social status and quality of citizens' life. 
Achieving the European quality of education in Ukraine will be a powerful factor in fulfilling the economic, political and cultural tasks of European integration of our country, building a prosperous and democratic society. Therefore, both in the context of European integration and in the context of ensuring the proper quality of life of the population, the state and society should consider the educational sphere as a priority.

It should be notified that the actual circumstances of educational cooperation with the EU, its assistance in developing the Ukrainian education system may not be sufficient. However, one should not expect that the EU will urgently do something useful for the educational system of Ukraine. Instead, it is necessary to ensure the development of the national system of education, to achieve improvement of its quality at all levels. Then our education system can fit into the European Education Area, become its full-fledged part. Unfortunately, we still do not always realize how many issues depend on ourselves in the process of European integration of Ukraine.

Ukraine has experience of European integration in the area of higher education already; it takes a very active part in the Bologna process. However, national higher education cannot be qualitative and European if we do not pay due attention to the quality of preschool and general secondary education. After all, students are former pupils. The success of the training of these young people in higher education institutions depends on the quality of their general secondary education, on the acquired knowledge, skills, experience, values, their competences acquired in the secondary education institution. Therefore, we need to identify and set the objectives of cooperation with the EU countries in the area of general secondary education, to participate in a more active way in the relevant European educational projects.

Integration into the European Education Area will enable us to formulate and solve the main didactic issues of general secondary education in a new way, namely:

- what kind of goals and objectives of education and training will be faced by the national system of general secondary education as a result of the deployment of European integration processes;

- which content of general secondary education will correspond to these updated goals and objectives of education and training; what key 
competences of students should be enhanced by the general secondary education of Ukraine at the present stage; in what way it will affect the State Standards for elementary and basic, general secondary education, curricula, educational programs;

- which methods and means of training will enable them to achieve the stated goals and content effectively;

- which forms of organization of training will remain relevant, will be simultaneously effective, reliable and economical under the new conditions; what parameters will reform the classroom teaching system in the context of mass implementation of information and communication technologies;

- by what criteria and indicators and with the help of which technologies, the results of education and training will be monitored and evaluated;

- how the integral process of studying in a secondary educational institution will look like and function, provided that the issues mentioned above are systematized and implemented;

- what requirements for the teaching and methodological support of general secondary education in Ukraine will be like;

- what kind of quality of general secondary education in Ukraine should be in the context of European integration.

Taking into account the abovementioned issues, one of the priorities of integration of the education system, in particular, the integration of the general secondary education of Ukraine into the European Education Area is to ensure its European quality.

2.2. Secondary education quality in Ukraine in the context of integration into European education area

EU's educational institutions regard the issue of education quality as a key one, and its optimization is considered as one of the necessary conditions for the socio-economic progress, development of human capital.

We cover this category in more detail. The education quality is its compliance with a certain norm, a standard that guarantees the status and effectiveness of the educational process, its ability to ensure the psychological and social development of a human, the needs and expectations of an individual, the 
demands of a particular social group and society as a whole. The education quality can be considered in the absolute (as the education corresponds to the needs and demands of the individual and society), and in the relative dimension (as the correspondence of education to the state standard, the curriculum). This definition makes it clear that the quality of education has not only pedagogical and psycho-pedagogical significance, but also social, economic, finally, political one. After all, high-quality education of citizens is an indicator of the human capital of the state, a guarantee of its competitiveness in the political, economic, scientific, cultural, even military areas. Long-known examples are such countries as Japan or Singapore, where there are no minerals, but which are developed and prosperous due to education and diligence of their population. Thus, the quality of education is important for the development, competitiveness, security and stability of the modern state.

One of the notable trends in the development of the national education systems in the EU member states is standardization. However, these are national educational standards. Discussing the general secondary education, these standards, as normative documents, are still in the long run. However, the notion of "European standards of secondary education quality" is not meaningless. We can think of it in a set of principles, norms and requirements to the quality of general secondary education, which are typical for the EU member states, which are discussed in the process of their educational cooperation. These requirements can be "read" and comprehended by our educators, they can become a guide for development, a measure of the results of the activity of secondary educational institutions of Ukraine.

The EU encourages its Member States to improve the quality of education and training programs in two strategic directions: firstly, by setting targets and publicizing Member States' positions on their achievement, and secondly, by discussing issues of mutual interest. It can be argued that improving the quality of education and ensuring equal access to it is one of the priorities of the internal policies of the member states of the EU. It should be taken into account in the process of European integration of Ukraine; these problems need to be granted more attention in the process of developing the national education system. 
Educational cooperation with the EU member states and relevant European educational institutions will have a number of important applications for our country. We provide some examples.

The Executive Agency for Education, Culture, and Audiovisual Executive Agency (EACEA), which is responsible for funding a part of the EU programs in the area of education, culture, etc., has been operating since 2006. The most important program of the agency is Erasmus + . This program has become a successor to a number of programs, in particular the Comenius program, named after Jan Amos Komensky, the prominent Czech educator. The Comenius program allowed for more than 2 million students to take part in joint foreign projects.

The EU Agency for Education, Culture, and Audiovisual Executive Agency is responsible for managing the Eurydice Network (European Education Information Network), which has been operational since 1980. It has been providing comparisons of EU education policy and education systems, sharing successful educational practices. The materials printed or posted on the website of this network relate to statistical data on the national education systems of the European countries of the European Union, educational cooperation in Europe, training of preschool children, elementary education, use of information and communication technologies, study of foreign languages, civil, artistic and cultural education in European schools, assessment of students' learning outcomes, lifelong learning, students' key competencies, and much more. Ukrainian teachers can and should use the materials of this network. Unfortunately, although a significant part of these materials is freely available on the Internet, they have not received sufficient recognition among Ukrainian educators yet. The reason for this may be the lack of foreign language skills and English-speaking skills, in particular. However, the study and use of these materials would contribute to a better understanding of national scientists, teachers of pedagogical universities, heads of educational institutions, methodologists and teachers of the most important educational processes that take place in Europe, and in which we will take direct part soon. 
2.3. Teaching and methodological support problem for the secondary education quality

One of the most important problems of teaching and methodological support for the quality of general secondary education is the creation of high-quality educational and teaching-methodical literature (textbooks, manuals, other educational books) that must meet the requirements of the State Standard and the curriculum, meet the needs of teachers and students, public requests for education content. So it was, so it is now. The form of presentation and the possibilities of these sources of educational information may and should be changed in accordance with the development of information and communication technologies. It is quite possible that, after some time, we will witness the dominance of electronic manuals that completely oust the paper, but the very problem of creating educational information sources, ensuring their proper quality, does not remove it.

The Institute of Pedagogy of the National Academy of Educational Sciences of Ukraine is the leader in creating textbooks for the general secondary education. We hold an annual conference "Problems of a Modern Textbook"; therefore, we are highly interested in the requirements for textbook creation, the opportunities for it being ensured by the integration with the European Education Area.

Thus, in 1997-2003, under the guidance of the Directorate General for Education and Culture of the European Commission, a group of experts have developed the Quality Guide.

Currently, the European Educational Publishers Group (EEPG) is an influential coordinator of the implementation of these criteria in the practice of creating educational and teaching materials. Since 2009, this organization, together with the Frankfurt Book Fair and the International Association for Research on Textbooks and Educational Media (IARTEM), organizes and holds the BESA (Best European Schoolbook Award) Competition for the Best European Textbook. The evaluation of submitted materials for the contest is carried out according to eight criteria: compliance with the learning objectives (focus on students, relevance); transparency (clarity of objectives and expected results, clarity of presentation and substantiation); reliability (internal 
consistency, methodological integrity, textual integrity, accuracy, practicality); attractiveness (convenience, interactivity, diversity, emotional saturation); flexibility (the possibility of individualization of training, appropriateness of teaching materials for the implementation of various training tasks); productivity (transfer and integration of knowledge, cognitive development of a student); participation (active participation of a student in the learning process, personal interest, promotion of partnership); socialization (formation of extra social skills and intercultural awareness).

Most of these criteria and indicators are well known to national creators of textbooks, but authors and publishers of educational and teaching materials need to get acquainted with the experience of European countries, to take these materials into consideration.

2.4. Pedagogical prognostics - future of the national secondary education system

European integration of Ukraine and the entry of the national system of education into the European Education Area create favourable conditions and give rise to the new prospects for the development of Ukrainian pedagogy. For example, this statement is fully related to the development of theoretical and methodological foundations and the formation of new perspectives for the practical implementation of the results of research on didactic prognostics. The didactic prognostics that we consider as relatively independent branch of scientific knowledge that appeared in the middle of didactics and pedagogical prognostics; a scientific discipline that studies fundamental (theories, approaches, principles, etc.) and applied (models, technologies, methods and techniques) aspects of the process of didactical foreseeing. In our opinion, one of the main tasks of didactic prognostics at the present stage is to foresee changes in the material and technical bases, the definition of new teaching aids necessary for the successful realization of the tasks of this process, initiated by new social requests. The article defines the subject, structure and the most important areas of pedagogical prognosis, the formation of which will take place in the process of its development and differentiation. The subject of modern didactic forecasting, the purpose, tasks and directions of its application for solving the problems of the development of the education system at the present stage are determined and substantiated. 
One of the most important tasks of didactic forecasting should be the prediction of the general secondary education's quality in the future (in particular, in the context of solving the economic, political, social and cultural tasks that are set for our country by its European choice).

\section{Conclusions}

Therefore, the European choice of Ukraine and integration into the European Education Area of national education necessitate its compliance with the European standards in order to ensure high quality. This process involves compulsory aspects such as integrity, complexity, predictability, openness. European integration of Ukraine and the entry of the national education into the European Education Area create favourable conditions and new perspectives for the development of Ukrainian pedagogical science and education.

\section{References}

- Kremen, V. G. (2007) Qualitative education in the context of general civilization changes. Problems of quality: theoretical and practical aspects. Materials of the methodological seminar of the Academy of Pedagogical Sciences of Ukraine November 15, 2006, Kyiv.

- Lyashenko, O. I. (2013). Organizational and methodological support for monitoring studies of the quality of general secondary education: monograph. Kyiv, Pedagogical Thought.

- Lyashenko, O. I., Lukya, T. O., Bulax, I. E., \& Mug, M. R. (2012). Methodology and technology for asses, sing the activity of secondary educational institution: manual. Kyiv, Pedagogical Thought.

- The Evaluation Criteria of Best European Learning Materials Awards [Online]. Retrieved from http//www. belma - award. eu / About-BELMA. Html. [accessed on 15 October 2017]. 
The online version of this article can be found at: http://revped.ise.ro/category/2018-en/

\section{(cc) $\mathrm{BY}-\mathrm{NC}-\mathrm{SA}$}

This work is licensed under the Creative Commons Attribution-NonCommercial-ShareAlike 4.0 International License.

To view a copy of this license, visithttp://creativecommons.org/licenses/by-ncsa/4.0/ or send a letter to Creative Commons, $P O$ Box 1866, Mountain View, CA 94042, USA.
Versiunea online a acestui articol poate fi găsită la:http://revped.ise.ro/category/2018-ro/

\section{$( c c ) \longdiv { B Y - N C - S A }$}

Această lucrare este licen iată sub Creative Commons Attribution-NonCommercial-ShareAlike 4.0 International License.

Pentru a vedea o copie a acestei licen e, vizita $i$ http://creativecommons.org/licenses/by-nc-sa/4.0/ sau trimite i o scrisoare către Creative Commons, PO Box 1866, Mountain View, CA 94042, SUA. 